\title{
Effect of gelatin based edible coatings on quality of surimi from pearl mullet (Alburnus tarichi, Güldenstädt, 1814) during cold storage
}

\author{
Gülistan OKUTAN ${ }^{1}$ (D), Gökhan BORAN ${ }^{1 \star ~(1) ~}$
}

\begin{abstract}
A two-phase study was designed to investigate the effects of $\mathrm{pH}$ and salt concentration of washing solution on quality and yield of surimi from pearl mullet fillets and edible coatings on quality of the resultant surimi during cold storage. In the first phase, higher salt concentration increased gel strength of surimi and improved some other textural attributes. Surimi obtained by conventional method was found to be superior as higher yield, dry matter and protein contents were achieved. In the second phase of the study, surimi samples coated by 4 different coating formulations were stored at $4^{\circ} \mathrm{C}$ for 10 days along with fish mince and uncoated surimi as control. TVB-N values of coated samples were not significantly increased during storage while that of fish mince reached to $53.6 \mathrm{mg} / 100 \mathrm{~g}$ sample on the $7^{\text {th }}$ day of storage. Acidity of all samples increased leading to lower ultimate $\mathrm{pH}$ values while ultimate $\mathrm{pH}$ of coated samples was not significantly different from that of control. In general, gelatin and chitosan based edible coatings were found not meaningfully effective in extending the shelf life of surimi under conditions studied and coating formulations used with while surimi itself showed prolonged shelf life compared to fish mince.
\end{abstract}

Keywords: cold storage; edible coating; pearl mullet; seafood quality; surimi.

Practical Application: An endemic fish species, pearl mullet, can be utilized in surimi production as an alternative value-added seafood. In addition, edible coatings may be utilized in cold preservation of surimi for extended shelf life and quality.

\section{Introduction}

Surimi is a popular product especially in some Asian and American countries, usually obtained from low fat fish meat (Tsuda et al., 2015). In surimi production, muscle proteins are aimed to be isolated while lipids, blood, enzymes and sarcoplasmic proteins are discarded to obtain a high-quality protein mixture, which is then frozen in the presence of cryoprotectants $(\mathrm{Wu}$, 2016). Although about $60 \%$ of surimi is produced from haddock, this has recently diminished with successful use of other species (Park, 2000). Dry matter of surimi, which is a refined form of chopped fish, is mainly formed of muscle proteins. Surimi is used as a raw material in some imitated food products manufactured in various ways. These products such as shrimp, scallops and crab are imitated by surimi besides Japanese traditional food Kamaboko, which is also produced from surimi (Kolsarıc1 \& Ensoy, 1996). Surimi is a high-quality protein source and is naturally poor in lipids, cholesterol and calories (Şen et al., 2017). In addition, surimi may be used in production of antioxidant peptides and bioactive peptides by hydrolysis (Wang et al., 2020). In fact, washing water of surimi manufacturing, which is rich in proteins, may be utilized in fortification of food products in terms of their nutritional value (Oliveria et al., 2020).

Recently, health concerns related to food industry has gained tremendous attention both from consumers and scientists. Consumers prefer products that are not heat treated and free of food additives. Therefore, studies on processing techniques like non-thermal processing methods and new packaging materials have been on focus of recent researches from all over the globe. Edible films and coatings have been studied in terms of their potential in preserving the quality of seafood and extending their shelf life (Feng et al., 2016).

There are various polymers used as carrier in edible films and coatings, as well as many bioactive ingredients used for their useful effects like limitation of oxidation and microbial growth. Whey protein, for example, may be used in formulation of edible films and/or coatings, leading to superior mechanical properties in the presence of oligosaccharides (Fernandes et al., 2020). Corn starch is another polymer that can be used in active edible films, mechanical properties of which are greatly affected by mixing method and the level of added active ingredients (Santoso et al., 2019). Processing waste of various food manufacturing processes, like potato peel waste, may find a place in formation of edible films and coatings (Othman et al., 2017). Gelatin, on the other hand, is such a polymer widely used in studies on edible films and coatings, which is a hydrolyzed form of collagen, the major protein of connective tissue of animals (Calvarro et al., 2016). Gelatin is widely used in pharmaceuticals, foods and medical products, just to mention a few. Its films and coatings are edible and biodegradable that comes with no harm on environment and human health along with some technological advantages like low gas permeability, ease of application, low cost and widespread availability (Bahmanzadeh et al., 2018). 
Chitosan is de-acetylated form of chitin, which is the most common secondary polymer in the world derived from crustaceans such as shrimp and crab. Chitosan is a complex carbohydrate and a naturally derived ingredient, which has antimicrobial effects (Cisse et al., 2012; Feng et al., 2016). Pearl mullet (Alburnus tarichi, Güldenstädt, 1814) is an endemic fish species that lives in lakes and rivers of Van plateau, Turkey, and its annual harvest amount is approximately 13000 tons (K1lınççeker \& Küçüköner, 2003).

In this study, pearl mullet fillets were used to get fish mince as starting material for surimi production obtained by altered washing solutions differing in $\mathrm{pH}$ levels and salt concentrations to investigate the effects of different $\mathrm{pH}$ and salt levels on product yield, gel strength, protein and dry matter content along with some textural features of the resultant surimi. After the determination of the process leading to the highest yield and quality, a follow-up study was carried out to determine the effects of gelatin based edible coatings in 4 different formulations fortified with rosemary extract or rosemary oil on the quality of surimi stored at $4^{\circ} \mathrm{C}$ for 10 days during cold storage.

\section{Materials and methods}

\subsection{Materials}

Pearl mullet (Alburnus tarichi, Güldenstädt, 1814), an endemic fish species to Lake Van Basin, Turkey, was obtained from a local fish market, immediately brought to the laboratory on ice, washed by cold tap water, beheaded, eviscerated and filleted manually. Fillets were used in surimi production after mincing by a Waring blender (Stamford CT, USA). Process flow scheme of surimi production is given in Figure 1.

In formulation of edible coatings, bovine hide edible gelatin (Gel) was used as carrier polymer; both sorbitol (Sor) and glycerol (Gly) as plasticizers; \%90 deacetylated chitosan (Chi), rosemary extract (RE) and rosemary oil (RO) as antimicrobial and antioxidant agents, respectively. Abbreviations used for surimi groups and formulation of coating solutions applied are given below:

- SUR-C: No edible coating applied.

- SUR-1: 5\% Gel, 0.5\% Sor, 0.5\% Gly, 0.5\% Chi (Edible coating, EC).

- SUR-2: EC fortified with 1\% RE (EC+1\% RE).

- SUR-3: EC fortified with $2 \% \mathrm{RE}$ (EC+2\%RE).

- SUR-4: EC fortified with 2\% RO (EC+2\% RO).

All chemicals used in surimi production and analyses were of analytical grade and obtained from Sigma-Aldrich (Missouri, USA) and Merck (Darmstadt, Germany).

\subsection{Experimental design}

This study was carried out in two consequential stages, in the first of which surimi was produced from pearl mullet fillets by 10 different washing solutions in the second washing step to see the effects of $\mathrm{pH}$ and salt concentration on yield and quality of the resultant surimi. At the second, surimi considered to be the best according to the yield and quality was used for a storage trial in where the effect of edible coatings formulated with rosemary extract and rosemary oil was investigated during cold storage at $4^{\circ} \mathrm{C}$ for 10 days.

In the surimi production trial, 10 different surimi samples were obtained by different washing solutions in the second washing step as control that was just with distilled water (1), others were with solutions at 6 different $\mathrm{pH}$ levels of 4,5 , $6,7,8$, and 10 as set by 0.1 or $1 \mathrm{~N} \mathrm{HCl}$ and $\mathrm{NaOH}$ solutions appropriately (2-7) and at 3 different salt concentrations of $0.25,0.5$ and $1 \% \mathrm{NaCl}(\mathrm{w} / \mathrm{v})$ dissolved in distilled water $(8-10)$ as treatments. Therefore, only difference among the samples was washing solution used in the second washing step differing in $\mathrm{pH}$ level and salt concentration, considered to be the treatment, which affects the precipitation of myofibrillar proteins according to $\mathrm{pH}$ of washing solution and isoelectric point of the target proteins, and salting out effect for the target proteins according to the salt concentration of washing solution, respectively.

Surimi with the highest yield and quality was then used for coating and cold storage trial in where 5 groups of surimi samples were used, uncoated as control (1) and others coated by gelatin based edible coatings with no further active ingredients (2), fortified with rosemary extracts at 2 different concentrations ( 3 and 4 ) and finally

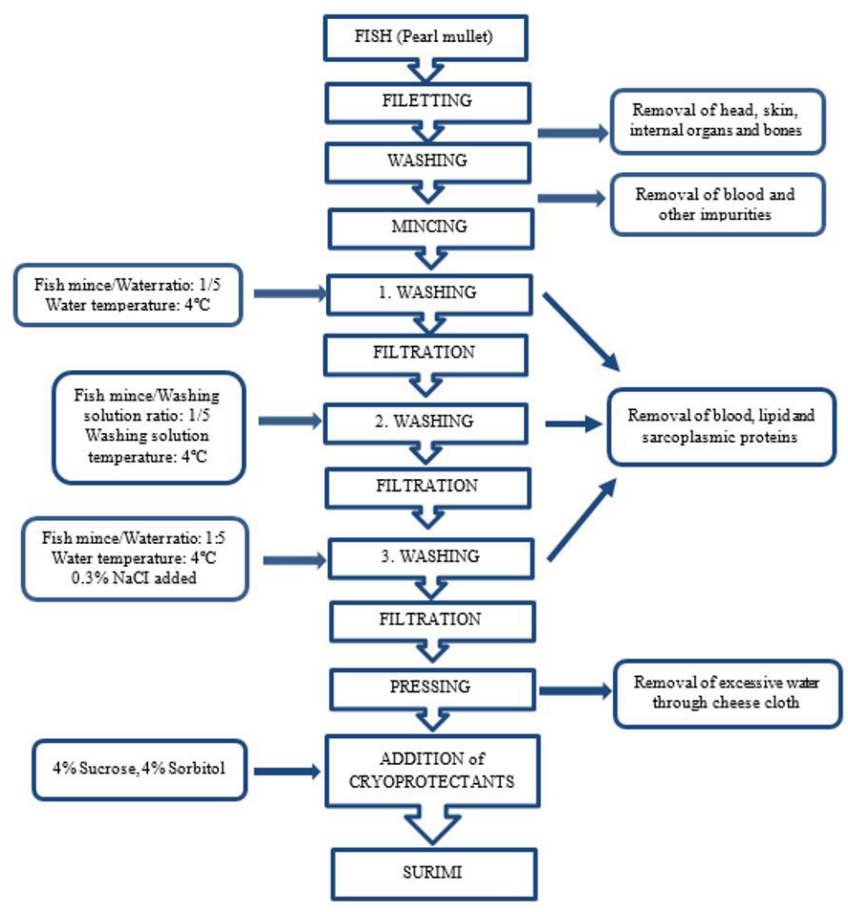

Figure 1. Process flow scheme for surimi production. 
fortified with rosemary oil (5). After surimi samples were formed in ice cube trays and coated by spraying, the samples were placed in zipped refrigerator bags and stored at $4^{\circ} \mathrm{C}$ for 10 days (Figure 2). Surimi production was duplicated and all analyses were triplicated unless otherwise was stated. Storage study was a one-time trial and all measurements were at least triplicated.

\subsection{Methods}

\section{Crude Nitrogen and Protein Content}

Crude protein content of the samples was determined by Kjeldahl method (Horwitz, 2002, AOAC 954.01). $12 \mathrm{~mL}$ of sulfuric acid and 1 piece of Kjeldahl tablet as catalyzer were added on approximately $1 \mathrm{~g}$ of sample. After successful incineration, the tubes were cooled before distillation. After addition of both $75 \mathrm{~mL}$ of distilled water and $\% 33 \mathrm{NaOH}$ solution to each tube, distillation was carried out until about $150 \mathrm{~mL}$ distillate was collected onto $25 \mathrm{~mL}$ mixture of boric acid, methyl red and bromine cresol green indicator. After distillation, titration was performed by $0.1 \mathrm{~N} \mathrm{HCl}$.

\section{Dry Matter and Crude Ash Content}

Dry matter and crude ash content of the samples were analyzed according to the methods of AOAC International (Horwitz, 2002, AOAC 934.01 and AOAC 942.05, respectively). $5 \mathrm{~g}$ of fresh sample was dried at $105^{\circ} \mathrm{C}$ until constant weight typically within 8 hours. Similarly, previously dried samples were used for analysis of crude ash content by incineration in porcelain crucibles at $550^{\circ} \mathrm{C}$ until constant weight typically within 5 hours. Both dry matter and crude ash content were calculated based on weight loss of the initial samples.

\section{Crude Fat Content}

Crude fat content was determined by solvent extraction according to the method by AOAC International (Horwitz, 2002, AOAC 960.39), in which $\mathrm{n}$-hexane was used as solvent. $5 \mathrm{~g}$ of sample was weighed into a paper cartridge and approximately 6 hours of extraction was carried out. Crude fat content was calculated based on gravimetrical difference.

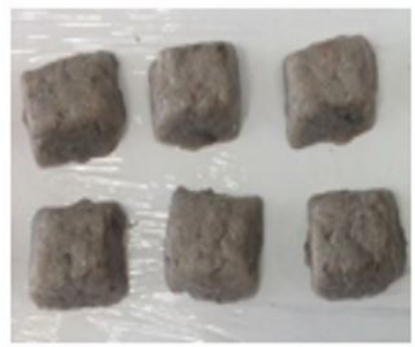

(a)

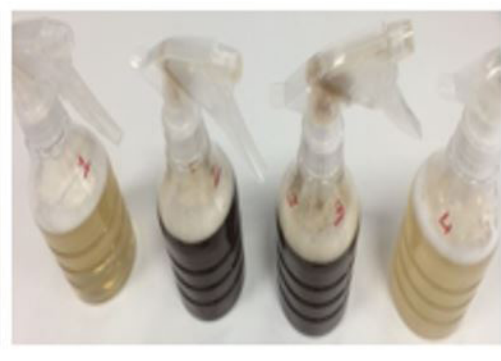

(b)

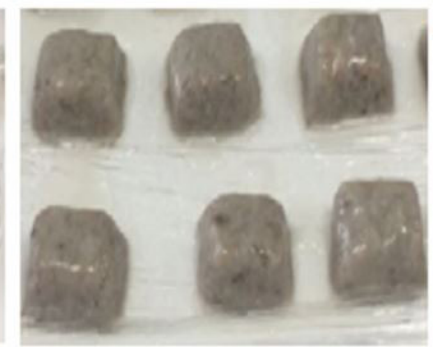

(c)

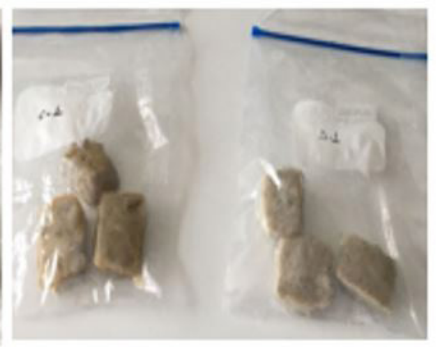

(d)

Figure 2. Formed surimi (a), coating solutions in sprayers (b), coated surimi samples (c), coated samples in zipped bags as stored (d). 
For calculation of cooking loss, an electric grill was used to cook each sides of formed surimi samples for $3 \mathrm{~min}$. After cooling the samples, cooking loss was calculated based on the difference between the weight of cooked surimi and its initial weight. The results were given according to the formula below:

Cooking $\operatorname{loss}(\%)=\frac{\text { Initial weight of surimi }- \text { Weight of cooked surimi }}{\text { Initial weight of surimi }} \times 100$

\section{Analysis of Color Difference}

Color measurements were taken from at least five different points of surimi samples using a colorimeter (CSM5, PCE Instruments, Southampton Hampshire, UK). Difference in color of samples during storage was determined by total color difference $(\Delta \mathrm{E})$ value according to the formula given below (Chinnaswamy \& Hanna, 1988).

$$
\Delta E=\sqrt{\left(L_{1}-L_{2}\right)^{2}+\left(a_{1}-a_{2}\right)^{2}+\left(b_{1}-b_{2}\right)^{2}}
$$

\section{Statistical Analysis}

The data was statistically analyzed by one-way analysis of variance to determine if there was any significant difference among the pairs. Tukey-Kramer test was utilized in order to determine which pairs were significantly different at a significance level of 0.05 using JMP 8.0 (SAS, NC, USA).

\section{Results and Discussion}

\subsection{Proximate composition of surimi}

Proximate composition of fish mince and surimi from pearl mullet fillets is given in Table 1. Surimi had slightly lower protein content compared to that of fish mince due to loss of sarcoplasmic proteins and non-protein nitrogen. Both fat and mineral contents of surimi were also lower than that of fish mince due to loss of these components during several washing treatments of surimi production. On the other hand, moisture content of surimi was slightly higher compared to that of fish mince at a negligible level. In a previous study reported by Süle (2011), mince and surimi obtained from Prussian carp (Carassius gibelio, Bloch, 1782) were also compared for their proximate composition and similar results were reported as such surimi was lower in protein, mineral and fat content in comparison with the mince. Moisture content, on the other hand, was higher in mince, which may be due to species specific differences.

Table 1. Proximate composition of fish mince and resultant surimi from pearl mullet (\%).

\begin{tabular}{lcccc}
\hline & Moisture & $\begin{array}{c}\text { Crude } \\
\text { protein }\end{array}$ & Crude fat & Mineral \\
\hline Fish mince & $77.6 \pm 0.1$ & $15.0 \pm 0.1$ & $4.1 \pm 0.1$ & $1.3 \pm 0.1$ \\
Surimi (control) & $78.8 \pm 0.1$ & $12.7 \pm 0.4$ & $1.4 \pm 0.2$ & $0.7 \pm 0.1$ \\
\hline
\end{tabular}

Values are in mean \pm standard deviation of triplicate measurements.

\subsection{Yield and some quality parameters of surimi}

Yield, gel strength, protein and dry matter content of surimi samples are given in Table 2. Surimi yield changed between 31.25 and $49.27 \%$ depending on $\mathrm{pH}$ level and salt concentration of solutions used in the second washing step. The highest yield was obtained in $\mathrm{pH} 4.0$ considering all 10 samples, 1 as control, 3 different in salt concentrations and 6 different in $\mathrm{pH}$ levels. However, this level of yield was not significantly different from that of those surimi samples obtained as control and by different salt concentrations. On the other hand, the rise of $\mathrm{pH}$ from 4.0 led to significantly lower yield values, most probably due to limited hydrolysis and precipitation of proteins at higher $\mathrm{pH}$ values. Higher yield in $\mathrm{pH} 4.0$ may be attributed to excessive hydrolysis of myofibrillar proteins at highly acidic conditions that resulted in higher amount of protein in surimi obtained, which is in part consistent with higher yield and dry matter content. It was also evident that the sample $\mathrm{pH} 10.0$ resulted in the lowest yield and dry matter content, which was probably due to excessive wash out of proteins and other non-protein content of fish mince. Although there were significant differences among the samples considering yield and dry matter content, the values were in a quite narrow range except the sample $\mathrm{pH}$ 10.0. Similarly, there were significant differences among protein content of surimi samples although that was within a rather narrow gap framed within 10.39 and $12.67 \%$.

Considering gel strength of surimi samples, it may be concluded that higher salt concentration resulted in higher gel strength, most probably due to potential role of salt ions as binding aid among protein structures. Lee et al. (2016) studied combined effect of $\mathrm{pH}$ and heating conditions on physical properties of surimi gels of Alaska Pollock. Surimi dough was prepared at different $\mathrm{pH}$ values (4.0-10.0) and a two-step heating was applied. Results concluded that deformability and gel strength were the highest at around $\mathrm{pH}$ 7.5-8.0. On the other hand, the lowest values of above-mentioned parameters were at $\mathrm{pH} 6.0$, 6.5 and 10.0. In addition, two-step heating treatment increased the breaking force by 2 times compared to one-step fast heating. Priyadarshini et al. (2017) reported a study in where tilapia fish mince was washed according to either traditional method or an alternative method in where alkaline salt (single wash) solution was utilized. Their results concluded that alternative method by alkali salt washing led to higher gel strength. Tahergorabi et al. (2012) investigated the effect of salt and salt substitutes on instrumental quality of surimi. Their results showed that salt and salt substitutes improved gel texture in surimi even at higher levels in case of salt compared to salt substitutes, which is consistent with the results reported in the present study.

\subsection{Textural attributes of surimi}

Textural attributes of surimi samples calculated based on TPA graphs are given in Table 3. The lowest hardness value was observed in $0.25 \% \mathrm{NaCl}$ sample although higher $\mathrm{NaCl}$ concentrations led to higher hardness values, consequently the highest in $1 \% \mathrm{NaCl}$ sample. Likewise, the highest cohesion value was obtained in $1 \% \mathrm{NaCl}$ surimi and the lowest in $0.25 \%$ $\mathrm{NaCl}$. The highest adhesion, on the other hand, was in surimi obtained by $\mathrm{pH} 10.0$ and the lowest was in $\mathrm{pH}$ 8.0. When it comes 
Table 2. Physical and chemical features of surimi obtained by different washing solutions.

\begin{tabular}{cllll}
\hline & \multicolumn{1}{c}{ Yield (\%) } & Dry matter (\%) & Protein (\%) & Gel strength (g) \\
\hline Control & $45.42 \pm 1.11^{\mathrm{ABC}}$ & $21.18 \pm 0.11^{\mathrm{CD}}$ & $12.67 \pm 0.42^{\mathrm{A}}$ & $383.10 \pm 9.73^{\mathrm{ABC}}$ \\
pH 4 & $49.27 \pm 1.04^{\mathrm{A}}$ & $25.24 \pm 0.38^{\mathrm{A}}$ & $11.90 \pm 0.51^{\mathrm{AB}}$ & $336.23 \pm 33.76^{\mathrm{BCD}}$ \\
pH 5 & $38.86 \pm 0.95^{\mathrm{CDE}}$ & $21.68 \pm 0.27^{\mathrm{C}}$ & $10.39 \pm 0.34^{\mathrm{C}}$ & $332.28 \pm 32.70^{\mathrm{CD}}$ \\
pH 6 & $41.32 \pm 4.66^{\mathrm{ABCD}}$ & $22.79 \pm 0.23^{\mathrm{B}}$ & $12.08 \pm 0.11^{\mathrm{AB}}$ & $263.81 \pm 9.49^{\mathrm{D}}$ \\
pH 7 & $34.90 \pm 3.59^{\mathrm{DE}}$ & $22.57 \pm 0.27^{\mathrm{B}}$ & $12.52 \pm 0.57^{\mathrm{A}}$ & $295.83 \pm 21.25^{\mathrm{CD}}$ \\
pH 8 & $39.31 \pm 2.29^{\mathrm{BCDE}}$ & $22.66 \pm 0.25^{\mathrm{B}}$ & $11.97 \pm 0.20^{\mathrm{C}}$ & $390.94 \pm 13.81^{\mathrm{ABC}}$ \\
pH 10 & $31.85 \pm 5.00^{\mathrm{E}}$ & $18.92 \pm 0.28^{\mathrm{E}}$ & $10.53 \pm 0.25^{\mathrm{C}}$ & $399.85 \pm 34.80^{\mathrm{AB}}$ \\
$\mathrm{NaCl} \mathrm{0.25 \%}$ & $48.30 \pm 3.90^{\mathrm{AB}}$ & $20.60 \pm 0.01^{\mathrm{D}}$ & $11.07 \pm 0.07^{\mathrm{BC}}$ & $261.15 \pm 2.80^{\mathrm{D}}$ \\
$\mathrm{NaCl} \mathrm{0.50 \%}$ & $47.78 \pm 1.93^{\mathrm{ABC}}$ & $22.68 \pm 0.41^{\mathrm{B}}$ & $10.59 \pm 0.89^{\mathrm{C}}$ & $321.22 \pm 17.27^{\mathrm{BCD}}$ \\
$\mathrm{NaCl} \mathrm{1 \%}$ & $42.73 \pm 1.56^{\mathrm{ABCD}}$ & $21.46 \pm 0.30^{\mathrm{C}}$ & $12.66 \pm 0.36^{\mathrm{A}}$ & $519.01 \pm 7.76^{\mathrm{A}}$ \\
\hline
\end{tabular}

Values are in mean \pm standard deviation of triplicate measurements. Different letters in the same column indicate significant difference among the samples at a significance level of 0.05 .

Table 3. Textural attributes of surimi from pearl mullet obtained by different washing solutions.

\begin{tabular}{clllllc}
\hline & Hardness & Cohesion & Adhesiveness & Springiness & Gumminess & Chewiness \\
\hline Control & $339 \pm 17^{\mathrm{DE}}$ & $0.60 \pm 0.05^{\mathrm{AB}}$ & $20.51 \pm 11.50^{\mathrm{AB}}$ & $68.60 \pm 4.24^{\mathrm{AB}}$ & $205.1 \pm 27.9^{\mathrm{C}}$ & $141.1 \pm 24.6^{\mathrm{D}}$ \\
pH 4 & $425 \pm 4^{\mathrm{BC}}$ & $0.64 \pm 0.02^{\mathrm{A}}$ & $14.94 \pm 3.06^{\mathrm{AB}}$ & $74.10 \pm 1.45^{\mathrm{A}}$ & $270.5 \pm 7.0^{\mathrm{B}}$ & $200.5 \pm 9.1^{\mathrm{B}}$ \\
pH 5 & $347 \pm 32^{\mathrm{DE}}$ & $0.62 \pm 0.01^{\mathrm{AB}}$ & $19.49 \pm 9.34^{\mathrm{AB}}$ & $71.91 \pm 1.30^{\mathrm{AB}}$ & $214.1 \pm 15.0^{\mathrm{C}}$ & $154.1 \pm 13.2^{\mathrm{CD}}$ \\
pH 6 & $458 \pm 44^{\mathrm{B}}$ & $0.61 \pm 0.03^{\mathrm{AB}}$ & $13.07 \pm 3.04^{\mathrm{AB}}$ & $68.56 \pm 2.63^{\mathrm{AB}}$ & $278.7 \pm 15.5^{\mathrm{B}}$ & $190.8 \pm 4.0^{\mathrm{BC}}$ \\
pH 7 & $318 \pm 6^{\mathrm{DE}}$ & $0.63 \pm 0.02^{\mathrm{AB}}$ & $25.72 \pm 9.01^{\mathrm{AB}}$ & $71.23 \pm 1.79^{\mathrm{AB}}$ & $201.01 \pm 7.7^{\mathrm{C}}$ & $144.0 \pm 9.1^{\mathrm{D}}$ \\
pH 8 & $303 \pm 9^{\mathrm{E}}$ & $0.64 \pm 0.03^{\mathrm{A}}$ & $6.16 \pm 1.21^{\mathrm{A}}$ & $71.10 \pm 3.00^{\mathrm{AB}}$ & $193.8 \pm 8.2^{\mathrm{C}}$ & $137.8 \pm 9.5^{\mathrm{D}}$ \\
pH 10 & $168 \pm 16^{\mathrm{F}}$ & $0.58 \pm 0.06^{\mathrm{AB}}$ & $45.64 \pm 27.13^{\mathrm{B}}$ & $70.04 \pm 10.06^{\mathrm{AB}}$ & $98.8 \pm 19.2^{\mathrm{D}}$ & $70.5 \pm 23.2^{\mathrm{E}}$ \\
$\mathrm{NaCl} \mathrm{0.25 \%}$ & $170 \pm 14^{\mathrm{F}}$ & $0.54 \pm 0.03^{\mathrm{B}}$ & $21.30 \pm 7.30^{\mathrm{AB}}$ & $59.78 \pm 6.19^{\mathrm{B}}$ & $91.6 \pm 9.0^{\mathrm{D}}$ & $55.0 \pm 9.5^{\mathrm{E}}$ \\
$\mathrm{NaCl} \mathrm{0.50 \%}$ & $373 \pm 17^{\mathrm{C}}$ & $0.58 \pm 0.03^{\mathrm{AB}}$ & $23.11 \pm 7.16^{\mathrm{AB}}$ & $67.25 \pm 2.54^{\mathrm{A}}$ & $215.6 \pm 18.9^{\mathrm{C}}$ & $144.8 \pm 9.7^{\mathrm{D}}$ \\
$\mathrm{NaCl} \mathrm{1 \%}$ & $519 \pm 12^{\mathrm{A}}$ & $0.67 \pm 0.03^{\mathrm{A}}$ & $16.91 \pm 10.81^{\mathrm{AB}}$ & $74.97 \pm 3.51^{\mathrm{A}}$ & $347.1 \pm 14.7^{\mathrm{A}}$ & $260.3 \pm 16.4^{\mathrm{A}}$ \\
\hline
\end{tabular}

Values are in mean \pm standard deviation of triplicate measurements. Different letters in the same column indicate significant difference among the samples at a significance level of 0.05 .

to springiness, the highest value was in surimi sample obtained by $1 \% \mathrm{NaCl}$ and the lowest was in $0.25 \% \mathrm{NaCl}$. Considering the chewiness, the highest value was in $1 \% \mathrm{NaCl}$ surimi and significantly different from other samples $(\mathrm{P}<0.05)$. The lowest chewiness and gumminess values were in $0.25 \% \mathrm{NaCl}$ surimi. Results showed that the concentration of $\mathrm{NaCl}$ in the second washing step significantly affected the textural attributes of surimi, as such the higher $\mathrm{NaCl}$ concentration, the greater textural attributes. In a study reported by Yu et al. (2017), surimi from silver carp was produced and compared with a commercial frozen surimi in the presence of different concentrations of different salts. They used $\mathrm{NaCl}$ at 1,2 and $3 \% ; \mathrm{KCI}$ at $1.27,2.55$ and $3.82 \%$; $\mathrm{CaCl}$ at $0.63,1.27$ and $1.89 \%(\mathrm{w} / \mathrm{w})$ and examined the effect of salts and their concentrations on textural and physicochemical properties of surimi. It was determined that hardness, chewiness and adhesion increased with higher salt concentrations while springiness did not change significantly.

Overall results showed that differences in the second washing step did not lead to significant differences in general, while higher salt concentrations resulted in some improvements in textural attributes. Therefore, the method as control for surimi production was concluded to be the best considering the yield, protein content and gel strength achieved; and surimi obtained accordingly was further used for coating and cold storage trial.

\subsection{Quality of coated surimi during cold storage}

\section{Change in Total Volatile Basic Nitrogen Content}

TVB-N is produced upon protein decomposition by microbial and enzymatic activity. TVB-N value is an important indicator of the level of protein degradation (Kong et al., 2017). TVB-N value is expected to increase during storage of high protein animal foods. In the present study, changes in surimi samples were, in general, slight and not stable. On the other hand, fish mince showed significant $(\mathrm{P}<0.05)$ and steady increase during storage and reached to a level of $54 \mathrm{mg}$ TVB-N/100 g sample at the $7^{\text {th }}$ day of storage (Table 4 ).

TVB-N of all surimi samples were below $6 \mathrm{mg}$ TVB-N/100 g sample during 10 days of cold storage (Table 4). Thaker et al. 
(2015) reported that TVB-N content of Indian salmon stored at $6^{\circ} \mathrm{C}$ reached to a level of $35.11 \mathrm{mg} / 100 \mathrm{~g}$ on the $8^{\text {th }}$ day of storage, which was consistent with our study, concluded a TVB-N value of $36.78 \mathrm{mg} / 100 \mathrm{~g}$ at the $7^{\text {th }}$ day of storage.

\section{Change in $\mathrm{pH}$ Value}

Change in $\mathrm{pH}$ of surimi samples during cold storage at $4^{\circ} \mathrm{C}$ for 10 days is given in Table 5. Generally speaking, $\mathrm{pH}$ value of all samples significantly decreased beginning from the $2^{\text {nd }}$ day of storage most probably due to increase in the concentration of organic acids upon microbial activity $(\mathrm{P}<0.05)$. Initial $\mathrm{pH}$ values of coated surimi samples were also slightly lower compared to that of control uncoated, most probably due to the ingredients used in the formulation of coatings. Eventually, all samples reached to the same ultimate $\mathrm{pH}$ level of about 4.7 except the control with 4.9, which was a negligible difference although significant $(\mathrm{P}<0.05)$ at the end of the 10 days of cold storage. In a study reported by Süle (2011), it was determined that initial $\mathrm{pH}$ value of fish mince increased upon addition of cryoprotectants. She

Table 4. Changes in TVB-N content (mg TVB-N/100 g sample) during cold storage.

\begin{tabular}{|c|c|c|c|c|c|c|}
\hline & Initial & Day 1 & Day 3 & Day 5 & Day 7 & Day 10 \\
\hline FM & $5.53 \pm 0.04^{\mathrm{d}}$ & $7.90 \pm 0.06^{\mathrm{d}}$ & $26.94 \pm 1.95^{\mathrm{c}}$ & $36.78 \pm 0.59^{b}$ & $53.55 \pm 2.14^{\mathrm{a}}$ & ND \\
\hline SUR-C & $2.56 \pm 0.03^{\mathrm{Bb}}$ & $2.71 \pm 0.12^{\mathrm{Ab}}$ & $2.73 \pm 0.09^{\mathrm{Bb}}$ & $5.30 \pm 0.22^{\mathrm{Aa}}$ & $2.72 \pm 0.03^{\mathrm{Ab}}$ & $5.11 \pm 0.04^{\mathrm{Aa}}$ \\
\hline SUR-1 & $5.29 \pm 0.43^{\mathrm{Aa}}$ & $2.77 \pm 0.01^{\mathrm{Ab}}$ & $5.43 \pm 0.08^{\mathrm{Aa}}$ & $2.69 \pm 0.05^{\mathrm{Bb}}$ & $2.45 \pm 0.05^{\mathrm{Ab}}$ & $2.66 \pm 0.13^{\mathrm{Bb}}$ \\
\hline SUR-2 & $2.62 \pm 0.04^{\mathrm{Ba}}$ & $2.74 \pm 0.04^{\mathrm{Aa}}$ & $2.75 \pm 0.05^{\mathrm{Ba}}$ & $2.57 \pm 0.05^{\mathrm{Ba}}$ & $2.36 \pm 0.36^{\mathrm{Aa}}$ & $2.73 \pm 0.05^{\mathrm{Ba}}$ \\
\hline SUR-3 & $2.73 \pm 0.03^{\mathrm{Bb}}$ & $2.69 \pm 0.12^{\mathrm{Ab}}$ & $2.67 \pm 0.09^{\mathrm{Bb}}$ & $2.74 \pm 0.08^{\mathrm{Bb}}$ & $2.77 \pm 0.01^{\mathrm{Ab}}$ & $5.25 \pm 0.09^{\mathrm{Aa}}$ \\
\hline SUR-4 & $5.35 \pm 0.04^{\mathrm{Aa}}$ & $2.69 \pm 0.14^{\mathrm{Ac}}$ & $3.95 \pm 1.67^{\mathrm{Aabc}}$ & $2.74 \pm 0.07^{\mathrm{Bbc}}$ & $2.64 \pm 0.10^{\mathrm{Ac}}$ & $5.13 \pm 0.23^{\mathrm{Aab}}$ \\
\hline
\end{tabular}

Values are in mean \pm standard deviation of triplicate measurements. Different lowercase letters in the same row indicate significant difference during storage. Different uppercase letters in the same column indicate significant difference among surimi samples $(\mathrm{P}<0.05)$. FM: Fish Mince, SUR-C: Uncoated Surimi, SUR-1: EC, SUR-2: EC+\%1 RE, SUR-3: EC+\%2 RE, SUR-4: EC+\%2 RO, ND: Not Determined.

Table 5. Changes in some quality indicators during cold storage of coated surimi.

\begin{tabular}{|c|c|c|c|c|c|c|c|}
\hline Indicator & Samples & Initial & Day 1 & Day 3 & Day 5 & Day 7 & Day 10 \\
\hline \multirow[t]{5}{*}{$\mathrm{pH}$} & SUR-C & $2.56 \pm 0.03^{\mathrm{Bb}}$ & $2.71 \pm 0.12^{\mathrm{Ab}}$ & $2.73 \pm 0.09^{\mathrm{Bb}}$ & $5.30 \pm 0.22^{\mathrm{Aa}}$ & $2.72 \pm 0.03^{\mathrm{Ab}}$ & $5.11 \pm 0.04^{\mathrm{Aa}}$ \\
\hline & SUR-1 & $5.29 \pm 0.43^{\mathrm{Aa}}$ & $2.77 \pm 0.01^{\mathrm{Ab}}$ & $5.43 \pm 0.08^{\mathrm{Aa}}$ & $2.69 \pm 0.05^{\mathrm{Bb}}$ & $2.45 \pm 0.05^{\mathrm{Ab}}$ & $2.66 \pm 0.13^{\mathrm{Bb}}$ \\
\hline & SUR-2 & $2.62 \pm 0.04^{\mathrm{Ba}}$ & $2.74 \pm 0.04^{\mathrm{Aa}}$ & $2.75 \pm 0.05^{\mathrm{Ba}}$ & $2.57 \pm 0.05^{\mathrm{Ba}}$ & $2.36 \pm 0.36^{\mathrm{Aa}}$ & $2.73 \pm 0.05^{\mathrm{Ba}}$ \\
\hline & SUR-3 & $2.73 \pm 0.03^{\mathrm{Bb}}$ & $2.69 \pm 0.12^{\mathrm{Ab}}$ & $2.67 \pm 0.09^{\mathrm{Bb}}$ & $2.74 \pm 0.08^{\mathrm{Bb}}$ & $2.77 \pm 0.01^{\mathrm{Ab}}$ & $5.25 \pm 0.09^{\mathrm{Aa}}$ \\
\hline & SUR-4 & $5.35 \pm 0.04^{\mathrm{Aa}}$ & $2.69 \pm 0.14^{\mathrm{Ac}}$ & $3.95 \pm 1.67^{\mathrm{Aabc}}$ & $2.74 \pm 0.07^{\mathrm{Bbc}}$ & $2.64 \pm 0.10^{\mathrm{Ac}}$ & $5.13 \pm 0.23^{\mathrm{Aab}}$ \\
\hline \multirow{5}{*}{$\begin{array}{c}\text { Storage Loss } \\
(\%)\end{array}$} & SUR-C & $0.54 \pm 0.14^{\mathrm{Bb}}$ & $1.64 \pm 0.47^{\mathrm{Cb}}$ & $9.29 \pm 1.94^{\mathrm{Aa}}$ & $12.39 \pm 0.98^{\mathrm{Aa}}$ & $12.12 \pm 1.64^{\mathrm{Aa}}$ & $0.54 \pm 0.14^{\mathrm{Bb}}$ \\
\hline & SUR-1 & $1.23 \pm 0.22^{\mathrm{Ad}}$ & $5.78 \pm 0.10^{\mathrm{ABc}}$ & $10.38 \pm 1.00^{\mathrm{Ab}}$ & $13.09 \pm 0.56^{\mathrm{Aa}}$ & $13.33 \pm 0.16^{\mathrm{Aa}}$ & $1.23 \pm 0.22^{\mathrm{Ad}}$ \\
\hline & SUR-2 & $1.23 \pm 0.06^{\mathrm{Ad}}$ & $6.22 \pm 0.27^{\mathrm{Ac}}$ & $10.63 \pm 0.30^{\mathrm{Ab}}$ & $13.17 \pm 0.29^{\mathrm{Aa}}$ & $13.34 \pm 0.62^{\mathrm{Aa}}$ & $1.23 \pm 0.06^{\mathrm{Ad}}$ \\
\hline & SUR-3 & $1.51 \pm 0.24^{\mathrm{Ad}}$ & $6.19 \pm 0.31^{\mathrm{ABC}}$ & $10.58 \pm 0.45^{\mathrm{Ab}}$ & $13.11 \pm 0.06^{\mathrm{Aa}}$ & $13.33 \pm 0.32^{\mathrm{Aa}}$ & $1.51 \pm 0.24^{\mathrm{Ad}}$ \\
\hline & SUR-4 & $1.15 \pm 0.11^{\mathrm{Ad}}$ & $5.24 \pm 0.48^{\mathrm{Bc}}$ & $10.68 \pm 0.41^{\mathrm{Ab}}$ & $13.26 \pm 0.18^{\mathrm{Aa}}$ & $13.46 \pm 0.31^{\mathrm{Aa}}$ & $1.15 \pm 0.11^{\mathrm{Ad}}$ \\
\hline \multirow{5}{*}{$\begin{array}{c}\text { Cooking Loss } \\
(\%)\end{array}$} & SUR-C & $56.41 \pm 3.75^{\mathrm{Aab}}$ & $59.84 \pm 3.56^{\mathrm{Aa}}$ & $41.11 \pm 0.19^{\mathrm{ABC}}$ & $48.28 \pm 0.36^{\mathrm{Abc}}$ & $56.26 \pm 0.60^{\mathrm{Aab}}$ & $51.65 \pm 0.37^{\text {Aab }}$ \\
\hline & SUR-1 & $52.03 \pm 0.85^{\mathrm{ABa}}$ & $40.87 \pm 0.73^{\mathrm{Bb}}$ & $50.28 \pm 0.29^{\mathrm{Aa}}$ & $52.87 \pm 1.07^{\mathrm{Aa}}$ & $45.08 \pm 3.17^{\mathrm{Bab}}$ & $45.57 \pm 1.59^{\mathrm{ABa}}$ \\
\hline & SUR-2 & $58.66 \pm 4.10^{\mathrm{Aa}}$ & $36.41 \pm 4.66^{\mathrm{Bb}}$ & $47.16 \pm 5.36^{\mathrm{Aab}}$ & $44.28 \pm 7.98^{\mathrm{Aab}}$ & $46.64 \pm 1.89^{\mathrm{Bab}}$ & $46.54 \pm 0.74^{\mathrm{ABab}}$ \\
\hline & SUR-3 & $49.02 \pm 3.03^{\mathrm{Aa}}$ & $36.96 \pm 0.25^{\mathrm{Bc}}$ & $41.02 \pm 0.02^{\mathrm{ABbc}}$ & $47.83 \pm 0.70^{\mathrm{Aa}}$ & $41.64 \pm 2.67^{\mathrm{Bbc}}$ & $45.33 \pm 1.44^{\mathrm{ABab}}$ \\
\hline & SUR-4 & $45.00 \pm 4.98^{\mathrm{Aa}}$ & $41.26 \pm 7.17^{\mathrm{Ba}}$ & $34.80 \pm 0.42^{\mathrm{Ba}}$ & $44.24 \pm 1.06^{\mathrm{Aa}}$ & $41.08 \pm 0.95^{\mathrm{Ba}}$ & $42.94 \pm 0.81^{\mathrm{Ba}}$ \\
\hline \multirow[t]{5}{*}{$\Delta \mathrm{E}$ Value } & SUR-C & - & $1.91 \pm 0.37^{\mathrm{Ac}}$ & $10.09 \pm 1.52^{\mathrm{Ab}}$ & $14.57 \pm 3.08^{\mathrm{Bab}}$ & $16.73 \pm 2.77^{\mathrm{Ba}}$ & $15.57 \pm 2.63^{\mathrm{Bab}}$ \\
\hline & SUR-1 & - & $2.98 \pm 1.82^{\mathrm{Aa}}$ & $7.76 \pm 1.41^{\mathrm{Aa}}$ & $8.35 \pm 1.56^{\mathrm{Ba}}$ & $7.16 \pm 2.25^{\mathrm{Ba}}$ & $6.47 \pm 4.05^{\mathrm{Ba}}$ \\
\hline & SUR-2 & - & $2.67 \pm 1.18^{\mathrm{Aa}}$ & $6.05 \pm 4.47^{\mathrm{Aa}}$ & $7.41 \pm 1.27^{\mathrm{Aa}}$ & $2.34 \pm 1.06^{\mathrm{Aa}}$ & $5.13 \pm 1.98^{\mathrm{Aa}}$ \\
\hline & SUR-3 & - & $3.87 \pm 3.01^{\mathrm{Aa}}$ & $6.11 \pm 2.83^{\mathrm{Aa}}$ & $6.55 \pm 1.81^{\mathrm{ABa}}$ & $7.24 \pm 2.35^{\mathrm{Ba}}$ & $9.37 \pm 7.30^{\mathrm{Ba}}$ \\
\hline & SUR-4 & - & $4.56 \pm 3.03^{\mathrm{Aa}}$ & $1.54 \pm 1.18^{\mathrm{Aa}}$ & $3.18 \pm 1.55^{\mathrm{Ba}}$ & $7.73 \pm 2.93^{\mathrm{Ba}}$ & $6.70 \pm 4.27^{\mathrm{Ba}}$ \\
\hline
\end{tabular}

Values are in mean \pm standard deviation of triplicate measurements. Different lowercase letters in the same row indicate significant difference during storage while different uppercase letters in the same column indicate significant difference among surimi samples $(\mathrm{P}<0.05)$ separately for each parameter. FM: Fish Mince, SUR-C: Uncoated Surimi, SUR-1: EC, SUR-2: EC+\%1 RE, SUR-3: EC+\%2 RE, SUR-4: EC+\%2 RO. 
also determined that $\mathrm{pH}$ value increased with 90 days of storage, which was expected because of amine formation upon protein hydrolysis. In the present study, storage was not probably long enough to see that increase in pH. Turan \& Sönmez (2010) produced 2 groups of surimi from stingray (Raja clavata) fish. The first group included $4 \%$ of sorbitol, $4 \%$ of sucrose and $0.3 \%$ of sodium tripolyphosphate, and the second group was with $8 \%$ of sorbitol and $0.3 \%$ of sodium tripolyphosphate. They stored surimi samples at $-23.8 \pm 2^{\circ} \mathrm{C}$ for 6 months and observed that $\mathrm{pH}$ of the first group was 7.34 while it was 6.98 in the second group, indicating that cryoprotectants and their levels are effective on $\mathrm{pH}$ of surimi significantly. $\mathrm{pH}$ of fish muscle is affected by many factors including initial microbial load and microflora, storage conditions, packaging and related measures, etc. An initial drop but later ultimate rise in $\mathrm{pH}$ was associated with microbial activity at first resulted in organic acids and further hydrolysis of proteins leading to volatile amines, respectively (Thaker et al., 2015).

\section{Storage and Cooking Loss Values}

Storage loss is an indicator of weight loss as vaporization and was observed in all samples during cold storage, which was significant but slightly in higher levels for coated samples, due to loss from coating itself. The difference between coated and uncoated samples was also significant $(\mathrm{P}<0.05)$. Weight loss in control reached to a level of $12 \%$ at the end of 10 days of cold storage while that was about $13 \%$ in uncoated samples. There was no significant difference among coated samples in terms of weight loss. It was observed that initial weight loss rate decreased after 5 days of cold storage (Table 5). The highest loss was found in SUR-4 with $13.36 \pm 0.31$ percent.

Cooking loss value, on the other hand, determines the amount of water lost during cooking. It is associated with water holding capacity of meat proteins. The greater water holding capacity leads to the lower cooking loss (Alakrash et al., 2016). Significant differences were observed in cooking loss value of the samples $(\mathrm{P}<0.05)$. Initially high values of cooking loss decreased at first with storage due to water loss but later increased significantly again with further storage. Generally speaking, it might be concluded that cooking loss came to an equilibrium level of $45 \%$ for coated samples while it was about $55 \%$ for uncoated control.

\section{Change in Color}

$\mathrm{L}$ value indicates brightness and increased in all surimi samples significantly $(\mathrm{P}<0.05)$ while differences between surimi samples were insignificant. A steady increase was observed in control reaching the highest $\mathrm{L}$ value among the other samples. Ramirez-Guerra et al. (2018) reported significant decrease in $\mathrm{L}$ value of uncoated and coated Pacific sierra fish during cold storage. The color of fish may be quite different from its surimi and might increase in $\mathrm{L}$ value during cold storage. Considering the value of a, it was slightly negative, indicating negligible greenness, and did not changed significantly during storage in all samples. When it comes the value of $b$, it was slightly positive, which indicates slight yellowness, but did not significantly differ among the samples during cold storage. Şen et al. (2017) measured color of surimi from sardines and haddock. It was reported that $\mathrm{L}$ value decreased by storage while the values of $\mathrm{a}$ and $\mathrm{b}$ increased. For better evaluation of color change in samples, color difference $(\Delta \mathrm{E})$ was calculated, which is given in Table 5. $\Delta \mathrm{E}$ increased in uncoated surimi during cold storage, which was significant $(\mathrm{P}<0.05)$. However, changes in $\Delta \mathrm{E}$ value of coated samples were not significant, indicating that all coating treatments were successful in limiting discoloration of surimi during cold storage.

\section{Conclusions}

Surimi from pearl mullet was studied for the first time. This study is also one of the few studies on use of edible coatings in seafood. It is concluded that gel strength and some textural attributes of surimi showed enhanced characteristics by increase in salt concentration of the second washing fluid in a limited manner. Nevertheless, alteration of $\mathrm{pH}$ and salt concentration of the second washing fluid did not lead to a superior surimi in terms of yield and quality. Gelatin based edible coatings formulated with rosemary extract and oil were effective, to some extent, on the quality of surimi during cold storage in spite of their own drawbacks. It is noteworthy that cooking loss and discoloration was limited in surimi samples by coating. It was also concluded that pearl mullet may be utilized in surimi production, providing a more durable seafood of pearl mullet and an alternative way of consumption. Further research is needed for optimization of formulation of edible films and coatings and their expected use for extension of shelf life of seafood products.

\section{Acknowledgements}

Authors gratefully acknowledge the funding provided by "The Administration of Scientific Research Projects of Van YüzüncüYll University” under the project: FYL-2018-6844.

\section{References}

Alakrash, F., Anyanwu, U., \&Tahergorabi, R. (2016). Physicochemical properties of Alaska Pollock (Theragrachalcograma) surimi gels with oat bran. Food Science and Technology, 66, 41-47. http://dx.doi.org/10.1016/j.lwt.2015.10.015.

Bahmanzadeh, S., Ruzgas, T., \&Sotres, J. (2018). Proteolytic degradation of gelatin-tannic acid multilayers. Journal of Colloid and Interface Science, 526, 244-252. http://dx.doi.org/10.1016/j.jcis.2018.04.112. PMid:29738939.

Bourne, M. (2002). Food texture and viscosity: concept and measurement (pp. 183-4). New York: Academic Press. http://dx.doi.org/10.1016/ B978-012119062-0/50001-2.

British Standards Institution - BSI. (1975). Methods for sampling and testing gelatin (Physical and Chemical Methods). London: BSI.

Calvarro, J., Perez-Palacios, T., \&Ruiz, J. (2016). Modification of gelatin functionality for culinary applications by using transglutaminase. International Journal of Gastronomy and Food Science, 5, 27-32. http://dx.doi.org/10.1016/j.ijgfs.2016.11.001.

Chinnaswamy, R., \&Hanna, M. A. (1988). Expansion, color and shear strength properties of corn starches extrusion-cooked with urea and salts. Stärke, 5(5), 186-190. http://dx.doi.org/10.1002/star.19880400507.

Cisse, M., Montet, D., Loiseau, G., \&Ducamp-Collin, M.-N. (2012). Influence of the concentrations of chitosan and glycerol on 
edible film properties showed by response surface methodology. Journal of Polymers and the Environment, 20(3), 830-837. http://dx.doi.org/10.1007/s10924-012-0437-2.

Feng, X., Bansal, N., \&Yang, H. (2016). Fish gelatin combined with chitosan coating inhibits myofibril degradation of Golden Pomfret (Trachinotus blochii) fillet during cold storage. Food Chemistry, 200, 283-292. http://dx.doi.org/10.1016/j.foodchem.2016.01.030. PMid:26830590.

Fernandes, L. M., Guimaraes, J. T., Silva, R., Rocha, R. S., Coutinho, N. M., Balthazar, C. F., Calvalcanti, R. N., Piler, C. W., Pimentel, T. C., Neto, R. P. C., Tavares, M. I. B., Esmerino, E. A., Freitas, M. Q., Silva, M. C., \&Cruz, A. G. (2020). Whey protein films added with galactooligosaccharide and xylooligosaccharide. Food Hydrocolloids, 104, 105755. http://dx.doi.org/10.1016/j.foodhyd.2020.105755.

Horwitz, W. (2002). Official Methods of Analysis of AOAC International (17. ed.). MD, USA: AOAC International.

Kılınççeker, O., \&Küçüköner, E. (2003). Tuzlanmış İnci Kefali (Chalcalburnus tarichi) balığında fiziksel, kimyasal ve biyokimyasal değişimlerin saptanması. Yüzüncü Yıl Üniversitesi, Ziraat Fakültesi. Tarım Bilimleri Dergisi, 13(1), 55-59.

Kong, H., Zhou, B., Hu, X., Wang, X., \&Wang, M. (2017). Protective effect of Perilla (Perilla frutescens) leaf essential oil on the quality of a surimi-based food. Journal of Food Processing and Preservation, 13540. http://dx.doi.org/10.1111/jfpp.13540.

Kolsarıc1, N., \&Ensoy, Ü. (1996). Surimi teknolojisi.Gıda Dergisi, 21(6), 389-401.

Lee, M. G., Yoon, W. B., \&Park, J. W. (2016). Combined effect of $\mathrm{pH}$ and heating conditions on the physical properties of Alaska Pollock surimi gels.Journal of Texture Studies, 48(3), 215-220. http://dx.doi.org/10.1111/jtxs.12230. PMid:28573722.

Olgunoğlu, İ. A. (2007). Marine Edilmiş Hamside (Engraulis engrasicholus L., 1758) Duyusal, Kimyasal ve Mikrobiyolojik Değişimler (Ph.D. Thesis). Çukurova University, Adana, Turkey.

Oliveria, D. L., Grass, T. L. M., Bassani, J. S., Diniz, J. C. P., Paiva, N. M., \&Ponsano, E. H. G. (2020). Enrichment of fish burgers with proteins from surimi washing water. Food Science and Technology (Campinas), (In Press). http://dx.doi.org/10.1590/fst.21319.

Othman, S. H., Edwal, S. A. M., Risyon, N. P., Basha, R. K., \&Talib, R. A. (2017). Water sorption and water permeability properties of edible film made from potato peel waste. Food Science and Technology, 37(Suppl. 1), 63-70. http://dx.doi.org/10.1590/1678-457x.30216.

Park, J. W. (2000). Surimi and surimi seafood.New York: Marcel Dekker, Inc.

Priyadarshini, B., Xavier, K. A. M., Nayak, B. B., Dhanapal, K., \&Balaange, A. K. (2017). Instrumental quality attributes of single washed surimi gels of tilapia: Effect of different washing media.Food Science and Technology (Campinas), 86, 385-392. http://dx.doi.org/10.1016/j. lwt.2017.08.022.

Ramirez-Guerra, H. E., Castillo-Yanez, F. J., Montano-Cota, E. A., Ruiz-Cruz, S., Marquez-Rios, E., Canizales-Rodriguez, D. F.,
Terres-Arreola, W., Montoya-Camacho, N., \&Ocano-Higuera, V. M. (2018). Protective effect of an edible tomato/chitosan coating on the quality and shelf life of Sierra fish fillets. Journal of Chemistry, 2018, 1-6.

Santoso, B., Hazirah, R., Priyanto, G., Hermanto, D., \&Sugito, D. (2019). Utilization of UncariagambirRoxb filtrate in the formation of bioactive edible films based on corn starch.Food Science and Technology (Campinas), 39(4), 837-842. http://dx.doi.org/10.1590/fst.06318.

Soares, N. M., Mendes, T. S., \&Vicente, A. A. (2013). Effect of chitosanbased solutions applied as edible coatings and water glazing on frozen salmon preservation. Journal of Food Engineering, 119(2), 316-323. http://dx.doi.org/10.1016/j.jfoodeng.2013.05.018.

Süle, Ö. (2011). Carassius gibelio'dan Surimi Yapımı ve Kimyasal ve Mikrobiyolojik Kalitenin Belirlenmesi (Master's thesis). Suleyman Demirel University, Isparta, Turkey.

Şen, E. B., Çaklı, Ş., \&Kılınç, B. (2017). Dondurulmuş mezgit ve sardalyadan üretilen surimi ve surimi jellerinin kalite parametrelerindeki değişimler. Ege Journal of Fisheries and Aquatic Sciences, 34(1), 8191. http://dx.doi.org/10.12714/egejfas.2017.34.1.12.

Tahergorabi, R., Bearmer, S. K., Matak, K. E., \&Jaczynski, J. (2012). Salt substituon in surimi seafood and its effects on instrumental quality attributes.Food Science and Technology, 48, 175-181.

Thaker, M., Hanjabam, M. D., Gudipati, V., \&Kannuuhamy, N. (2015). Protective effect of fish gelatin-based natural antimicrobial coating on quality of Indian salmon fillets during refrigerated storage. Journal of Food Process Engineering, 40(1), 1-10. http://dx.doi. org/10.1111/jfpe.12270.

Tsuda, K., Nagano, H., Ando, A., Shima, J., \&Ogawa, J. (2015). Isolation and characterization of psychro-tolerant endospore-forming Sporosarcina species associated with minced fish meat (surimi). International Journal of Food Microbiology, 199, 15-22. http://dx.doi. org/10.1016/j.ijfoodmicro.2014.12.031. PMid:25621716.

Turan, H., \&Sönmez, G. (2010). Changes in proximate composition of Thornback Ray (Raja Clavata, L., 1758) surimi during washing and frozen storage. Journal of Food Processing and Preservation, 34, 24-34. http://dx.doi.org/10.1111/j.1745-4549.2008.00265.x.

Wang, P., Lin, Y., Wu, H., Lin, J., Chen, Y., Hamzah, S. S., Zeng, H., Zhang, Y., \&Hu, J. (2020). Preparation of antioxidant peptides from hairtail surimi using hydrolysis and evaluation of its antioxidant stability. Food Science and Technology (Campinas), 40(4), 945-955. http://dx.doi.org/10.1590/fst.23719.

Wu, S. (2016). Effect pollulan on gel properties of Scomberomorus niphonius surimi. International Journal of Biological Macromolecules, 93(Pt A), 1118-1120. http://dx.doi.org/10.1016/j.ijbiomac.2016.09.085. PMid:27670727.

Yu, N., Xu, Y., Jiang, Q., \&Xia, W. (2017). Textural and physicochemical properties of surimi gels prepared with potassium and calcium chloride as substitutes for sodium chloride. International Journal of Food Properties, 20, 1539-S1552. 